\title{
弦材にコンクリートを充填した平行弦鋼管トラスの変形能力 \\ THE DEFORMATION CAPACITIES OF PARALLEL CHORD TRUSSES WITH CONCRETE FILLED TUBULAR CHORDS
}

\author{
河野昭彦*, 松井千 秋** \\ Akihiko KAWANO and Chiaki MATSUI
}

\begin{abstract}
This paper presents a evaluation for the deformation capacity of a parallel chord truss of which the chord members are concrete filled circular tubes (CFT truss). The CFT truss could have a stable plastic collapse mechanism without any strength reductions under not only monotonous loading but also alternatively repeated loading, so that the encased concrete in tubular chords would well avoids the chord buckling. In this paper, the conditions for some stable mechanisms are described and the deformation capacities of CFT trusses are evaluated for each mechanism. The covering mechanisms are (1) none of the chords of a CFT truss buckles under monotonous loading; (2) none of the chords buckles under repeated loading; and (3) one of the chords buckles under repeated loading. A sample evaluation demonstrates that CFT trusses could have the superior deformation capacities which could be compared with full web members in steel.
\end{abstract}

Keywords: $\quad$ concrete filled tube, truss, beam-column, deformation capacity, buckling, fracture コンクリート充填鋼管, トラス, 梁柱, 変形能力, 座屈, 破断

\section{1. 序}

純鉄骨トラスの䨛力は,節点が十分な強度を持つとすれば構成部材 の曲げ座屈や骨組全体の座屈などの構造不安定によって決定されるの が普通である．しかし，コンクリート充填円形鋼管部材（CFT 部材） を弦材に使用した平行弦トラス (CFTトラス) では, 繰返し荷重下に おいても構造不安定を回避することが可能でありり，また弦材が座屈 した場合でも CFT 部材の優れた耐震性能が期待できる2)など優れた 耐震性能が期待できる.

CFT トラスの崩壊形式は,CFT部材が純鉄骨部材にはない軸方向挙 動上の特徴を持つため多彩である.CFT部材の特徴は, (a) 充填コンク リートが圧縮だけに抵抗するので,一方向圧縮の場合の座屈耐力が一 方向引張の場合の降伏耐力を上回る ${ }^{3)}$;(b) きわめて短柱であれば繰返 し軸力に対しても合成断面部材としての圧縮耐力を保持する4) が, そ うでなければ中空鋼管と同じ圧縮耐力になる5 ${ }^{5}$;(c) 局部座屈が発生し ても耐力少化が少なく，その後多数の繰返し荷重に耐える6)-8); など である、純鉄骨トラスに関しては, ラーメン骨組の梁材に限定して变

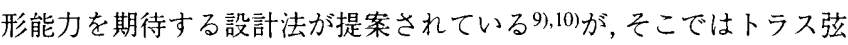
材の曲げ座屈は不可避の現象とされている，ところが，CFTトラス は, CFT 部材の特徵 (a) および (b) によって弦材の曲げ座屈を回避す ることができる。また, 純鉄骨トラスでは局部座屈発生点がトラスの
変形限界と考えられているが, CFTトラスは CFT 部材の特徴 (c) に よって鋼管の局部座屈後も耐力の保持やエネルギー吸収が期待できる ので, 局部座屈発生点を変形限界と考える必要はないと考えられる. ここでは，図 1 に示す而弦材が同断面の CFT 部材で構成された平 行弦 CFTトラスに対して, 弦材が曲げ座屈あるいは引張降伏, さら に局部座屈する場合に対する変形能力の評価を試みる.

\section{2. 一方向荷重下の変形能力 \\ 2.1 トラスの一方向荷重下の安定挙動 \\ (1) 一方向軸力を受ける CFT 部材の挙動と耐力}

図2(a),(b) は, CFT部材と中空鋼管部材の一方向圧縮あるいは一方 向引張の実験挙動である ${ }^{3)}$. 鋼管は, 冷間成形の電縫鋼管で径厚比は 約 30 である. 一方向圧縮力を受ける場合の座屈長さは, 鋼管外径の

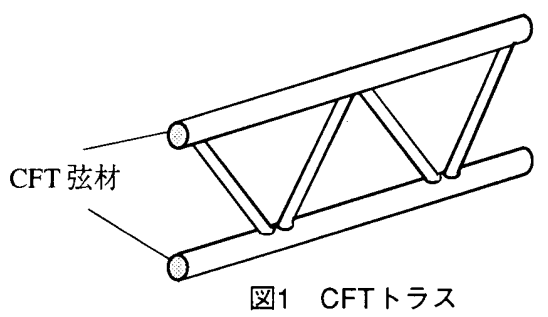

$*$ 九州大学人間環境学研究科 助教授 $\cdot$ 工博
$* *$ 九州大学人間環境学研究科 教授 $\cdot$ 工博
Assoc. Prof., Division of Human Environment Studies, Graduate School of Kyushu University, Dr. Eng.

Prof., Division of Human Environment Studies, Graduate School of Kyushu University, Dr. Eng. 


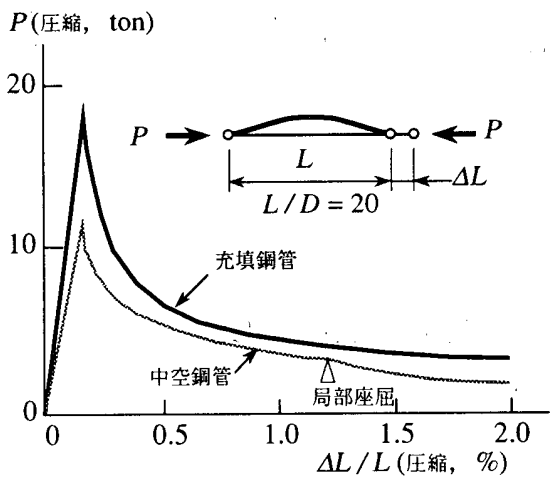

(a) 一方向圧縮挙動

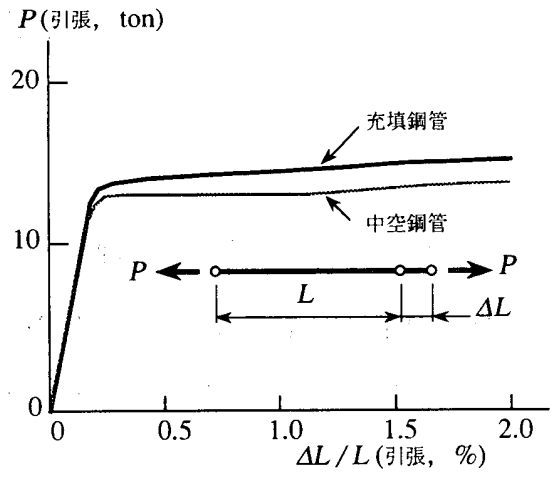

(b) 一方向引張挙動

図2 CFT部材および中空鋼管部材の一方向載荷挙動

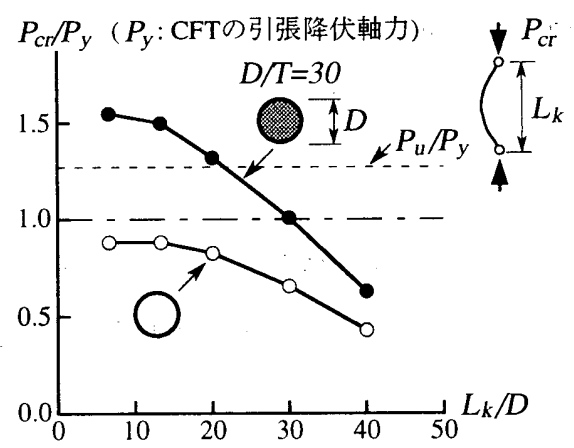

図3 CFT部材および中空鋼管部材の曲げ座屈荷重

20 倍 (鋼管の細長比 $\lambda$ で約 60) である. 充填コンクリートは普通コン クリートで, シリンダー圧縮強度 $\sigma_{B}$ は約 30MPa である. 図 2(a)に 示すように, 一方向圧縮の場合の CFT 部材の曲げ座屈荷重は中空鋼 管部材の場合よりり高くなるが, 曲げ座屈後の耐力劣化は中空鋼管部材 と同様に急激である.中空鋼管部材の場合は, さらに局部座屈が発生 して耐力劣化が加速する.一方, CFT 部材の場合は, 局部座屈の発生 は軸方向変位がかなり大きくなるまで発生せず, 3.1 節の繰返し軸力 を受ける場合で示すように,たとえ局部座屈が発生してもすぐには耐 力が劣化しない. 図 2(b) は一方向引張の場合を示す.CFT 部材の引 張降伏軸力は, 中空鋼管部材の場合より $10 \%$ 弱増加する。この耐力 上昇は, 鋼管が Mises の降伏条件に従うとすれば, 鋼管断面の半径方 向の収縮変形が充填コンクリートによって拘束を受けるので管壁が二 軸引張を受ける平面応力状態になることから説明できる.この拘束は 軸方向歪に対する相当塑性歪量を大きくするため, CFT部材の一様伸 び (近似的に最大軸力までの伸び) が中空鋼管部材の場合より減少す るが, 減少量は顕著ではなく7), 中空鋼管部材と同程度と考えること ができる、ただし，最大軸力以降の伸びは鋼管の絞り変形が生じない ためほとんどない。

図 3 は, 各種の座屈長さ $L_{k}$ を持つCFT 部材および中空鋼管部材の 曲げ座屈荷重の実験結果である3)。ただし，ここでは実験の最大圧縮 軸力を曲げ座屈荷重と見なした. 図中の記号 $D$ は鋼管の外径を表す. 鋼管は冷間成形電縫鋼管で径厚比は約 30 ,充填コンクリートの $\sigma_{B}$ は 約 30MPa である. 図の一点鎖線はCFT部材の引張降伏軸力 $P_{y}$, 破線 は最大引張軸力 $P_{u}$ を表す，図より，鋼管の座屈長さがある限界值以 下では, CFT 部材の曲げ座屈荷重 $P_{c r}$ が $P_{y}$ あるいは $P_{u}$ 以上になるこ とがわかる。もちろん, この座屈長さの限界值は鋼管の径厚比, 鋼管 とコンクリートの材料強度などによって変化するが,この例で示すよ うに比較的長柱の領域にある.

(2) CFT トラスの安定挙動の条件 I（引張弦材が降伏する条件）

図 4 は, 一方向荷重が作用する場合の CFT トラスと中空鋼管トラ スの材端モーメントとたわみ角の関係の実験結果1)である。トラスは 材端で構面外に単純支持され，等曲げ(圧縮弦材と引張弦材の軸力の 絶対値が等しい)を受ける. 弦材に使用した鋼管は冷間成形電縫鋼管 で径厚比 $D / T$ は約 30 , 降伏応力度 $\sigma_{y}$ は約 $320 \mathrm{MPa}$, 弦材の外径に 対する横補剛支点間距離の比は約 20 で, 充填コンクリートの $\sigma_{B}$ は 約 30MPa である. 図の太い実線で示すようにCFTトラスはたわみ角 の増加とともに材端モーメントが上昇し続ける安定した挙動を示して いる. 一方, 中空鋼管トラスは, 弦材の構面外座屈のためピーク後は
急激に材端モーメントが低下している.CFTトラスが安定した挙動を 示すのは,「引張側弦材の降伏軸力に対して圧縮側弦材の曲げ座屈軸 力が十分に大きい;トラスは片方の弦材が圧縮ならば他方は釣合条件 から同じ值で引張になる」という性質から, 圧縮側弦材の軸力は引張 側弦材の降伏で頭打ちとなってて決して座屈軸力に達しないためであ る.ただし，この場合は引張側弦材が降伏しているため，圧縮側弦材 の構面外座屈耐力に対して引張側弦材の補剛効果は期待できない.つ まり,压縮側弦材の構面外座屈は横補剛支点間距離を座屈長さとした ときの曲げ座屈荷重とする必要がある。もちろん, 横補剛支点を密に 設ければ, それだけ安定挙動を容易に実現することができる.ここで は, 圧縮弦材の座屈軸力が引張弦材の降伏軸力（もっとも安全側には 最大引張軸力）を上回る条件を「安定挙動の条件 I」と呼ぶ.

図 5 は,トラスに曲げモーメント $M$ のほか軸力 $N$ も作用する一般 的な荷重条件下での安定挙動の条件 I ${ }^{1)}$ を示している。これはCFTト ラスの M-N 相関耐力で, 縦軸はトラスに作用する軸力 $N$, 横軸は曲 げモーメント $M$ を表している. 図中の記号は, $N_{c r}=2 P_{c r 0}$ : トラスの 圧縮耐力 $\left(P_{c r 0}\right.$ : 他方の弦材やウエブ材の補剛効果を無視した座屈長 さに対する弦材の曲げ座屈軸力) , $N_{y}=2 P_{y}$ : トラスの引張降伏耐力

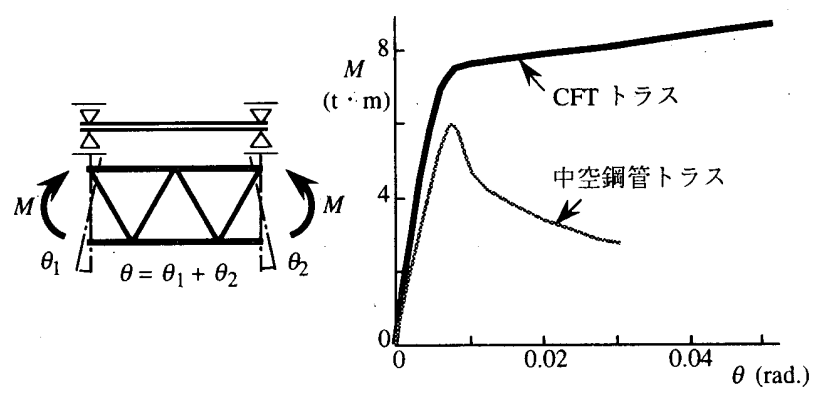

図4 CFTトラスの一方向載荷挙動

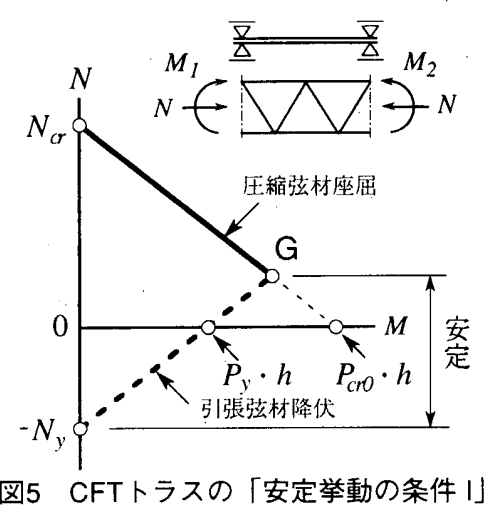


$\left(P_{y}\right.$ : 弦材の $\mathrm{CFT}$ 部材としての引張降伏軸力で, 充填コンクリートの 拘束による上昇を考慮する), $P_{y} \cdot h:$ トラスの降伏曲げモーメント $(h$ : 両弦材の断面重心間距離), $P_{c r} \cdot h$ : トラスの座屈モーメントである. CFTトラスのM-N相関耐力は弦材が曲げ座屈する場合の直線 $\left(N_{c r}\right.$ と $P_{c n n} \cdot h$ を結ぶ実線 $)$ と引張降伏する場合の直線 $\left(-N_{y}\right.$ と $P_{y} \cdot h$ を結ぶ 破線)の 2 本で構成されている. 安定挙動の条件 I はトラスの軸力 $N$

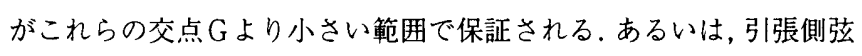
材が破断するまでトラスの安定挙動を保証するためには, 図の $P_{y} を$ $\mathrm{CFT}$ 部材としての最大引張軸力 $P_{u}$ に読み替える必要がある.

\section{2 トラスの一方向荷重下の変形能力}

安定挙動の条件 I を満たす CFTトラスの変形性能について検討す る.等曲げモーメントを受ける場合は引張側弦材が全長にわたって降 伏するのでトラスには十分な塑性変形が期待できる.一方, トラスが 曲げせん断を受ける場合は引張側弦材の塑性化が端部の 1 区間に集中 するので9),10), 変形性能に制的が生じる.この定量化のため, 図6に 示すトラスの塑性崩壊機構を考える.引張側弦材の塑性化は端部の材 長 $l$ (ここでは $l^{+}$を考える）の1区間に限られるものとし，その部 分の塑性伸びを $\Delta l_{p}$ とする. $\Delta l_{p}$ によってトラスには $R_{p}$ だけ塑性部 材角が生じる. 幾何学的に $R_{p}$ と $\Delta l_{p}$ の間には次の関係がある.

$$
R_{p}=\frac{\Delta l_{p}}{h}=\frac{\Delta l_{p}}{l} \cdot \frac{l}{h}
$$

さて, $R_{p}$ の最大值 $R_{p u}$ を小さめに見積もることを試みる.まず, $\Delta l_{p}$ /lの限界值は, CFT 部材の一様伸び歪に等しいとし, 普通鋼で冷間 成形された鋼管の下限值として $8 \%$ 程度を考える ${ }^{1)-33,5)-8) . ~ た た ゙ し, こ ~}$ の値の妥当性はデー夕を蓄積して検証する必要がある. 次に $l / h$ は 図6に示すワーレントラスの $l^{+}$が実用上の最小值を与えると考えて よく, ウェブ材の斜角を 60 度とすると $R_{p u}$ は次にようになる.

$$
R_{p u}=0.08 \cdot \frac{1}{\sqrt{3}}=0.046
$$

次にCFTトラスの塑性変形能力 $\eta$ は次式で定義することにする.

$$
\eta=\frac{R_{p u}}{R_{p c}}
$$

ここで, $R_{p c}$ は弾性限部材角（トラスが降伏モーメントに達したとき の弾性部材角) で, トラスそれぞれについて求める必要がある. $R_{p c}$ は, 主としてトラスのせん断スパン比 (格間数), ウェブ材と弦材の 断面寸法比に影響され, 前者はトラスの曲げ変形, 後者はトラスのせ ん断変形に関係している. 図7は $R_{p c}$ の計算例で, せん断スパン比 $M$ $/ Q d$ に対する $R_{p c}$ の変化を示している.これらは, ウェブ材の斜角が 60度のワーレン形 CFT トラスモデルに片持ち梁形式で自由端に横荷 重を作用したときの弾性骨組解析結果である.ここで， $R_{p c}$ は引張側 弦材の区間 1 の軸力が降伏軸力（ $\sigma_{y}=330 \mathrm{MPa}$ で 50 キ口鋼級を想定） に達したときの部材角としている.トラスモデルの鋼管とコンクリー トのヤング率はそれぞれ $200 \mathrm{kN} / \mathrm{mm}^{2}$ および $25 \mathrm{kN} / \mathrm{mm}^{2}$, 格間数は 2 $\sim 12$, 弦材鋼管の径厚比は 30 , ウェブ材の径厚比は 20 , ウェブ材と 弦材の外径比 $d / D$ は 0.4 と 0.7 である. 図より, せん断スパン比 $M /$ Qd が大きくなると弾性限部材角 $R_{p c}$ は, 曲げ変形のみの場合にそう であるようにほぼ線形に增大する，M/Qd が 5 程度以下で線形関係 が崩れるのは, ウェブ材の伸縮によるトラスのせん断変形の影響であ る. $d / D$ が 0.4 のトラスでは, $M / Q d$ が 3 程度以下ではウェブ材が座



図6 トラスの塑性崩壊機構モデル

屈軸力に達するので考虑外とする必要があるが, ウェブ材の変形, つ まりトラスのせん断変形が $R_{p c}$ を増大させる影響は小さくないことが わかる.さらに, トラス節点では弦材鋼管の局部変形によってウェブ 材の剛接度が低下しトラスのせん断変形を増大させるが,CFTトラス の節点剛性は未解明であるので計算に含めていない.また,ここに示 していないが, 弦材鋼管の径厚比 $D / T$ も弦材の軸剛性における充填 コンクリートの寄与率を変化させるので $R_{p c}$ に若干影響を与える.

図 8 は $R_{p u}$ を $4.6 \%$ と仮定した場合の式(3)のCFTトラスの塑性変 形能力 $\eta$ を示している．図には，文献9)による充腹柱および充腹梁 の構造ランクの規定值も示している.これによれば, CFTトラスの変 形能力は 3 から 10 程度になっており, 柱としては通常 II 以上は期待 できるが, I 以上はウェブ材の断面を大きくしない限り期待できない こと, 梁としては, $M / Q d$ が 14 程度までは構造ランクIに該当する ことなどがわかる.

ただし，トラスの限界部材角は塑性変形成分だけでも $4.6 \%$ に達し ている. 文献 11) は限界部材角が $2 \%$ 以上の CFT 柱をじん性がもっ

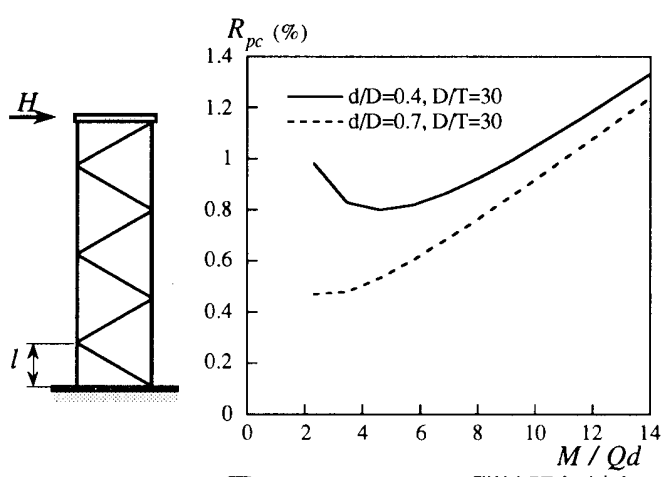

図7 CFT トラスの弾性限部材角

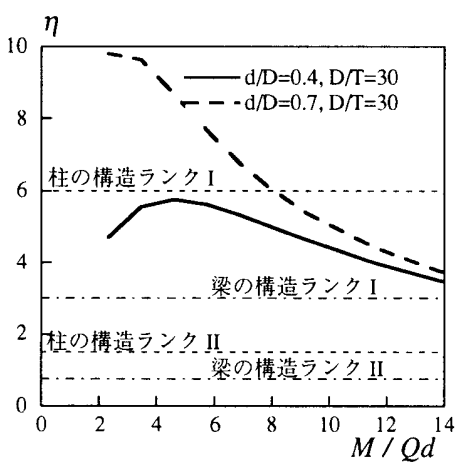

図8 CFT トラスの塑性変形能力 




(a) 大変位定振幅

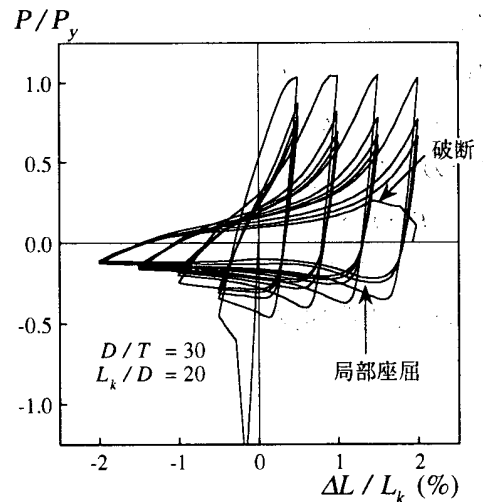

(b) CFT 部材, 漸增変位振幅

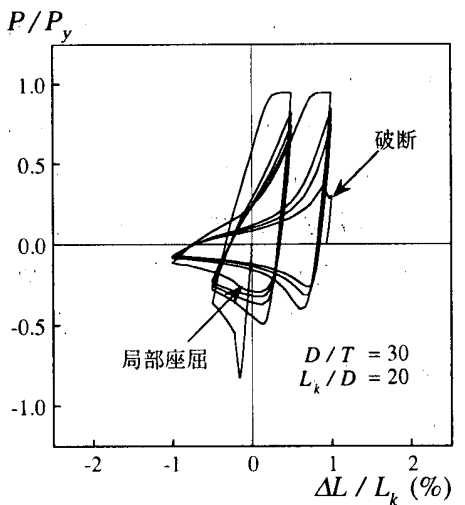

(c) 中空鋼管部材，漸増変位振幅

図9 CFT部材と中空鋼管部材の軸方向挙動

とも大きなFA ランクに位置づけている。したがって,これによれば CFTトラスは十分な塑性変形性能を持つとしてFA ランクに評価され ることになる。

\section{3. 繰返し荷重下の変形能力}

\section{$3.1 C F T$ 部材の繰返し荷重下の耐力と挙動}

CFT トラスの塑性変形能力は積雪などの一方向の過載荷重に対して は上述の方法で評価できる.しかし，CFTトラスは地震力などの繰返 し荷重に対しては一方向載荷の場合とはまったく異なった挙動を示す ので，上述の方法はそのままでは適用できない.そこで,まず CFT 部 材の繰返し軸力下の挙動を整理し，次にそれに基づいて CFTトラス の変形能力を評価する.

\section{(1) CFT 部材の軸方向繰返し挙動}

図 9(a) ( c) は, 座屈長さ - 外径比 $L_{k} / D$ が約 20 (鋼管の細長比で 60）の CFT 部材と中空鋼管部材の繰返し実験挙動 6$)$ で，鋼管の $D / T$ は約 30，应は約 $320 \mathrm{MPa} ，$ 充填コンクリートの $\sigma_{B}$ は約 30MPa であ る. 図9(a)の大変位振幅の実験結果より, CFT部材の第1サイクル目 の圧縮耐力（曲げ座屈荷重）は中空鋼管部材に比較して大きいが，第 2サイクル目では両者に差がないことがわかる．また，中空鋼管部材 では第 1 サイクルでの局部座屈発生とともに抵抗力が劣化し，第 2 サ イクルでは劣化がさらに顕著になるが, CFT 部材ではこの範囲では局 部座屈していない. 図9(b), (c) はそれぞれ漸増変位振幅の場合の CFT 部材および中空鋼管部材の軸方向挙動である。両図から, CFT 部材の 破断は中空鋼管部材に比較してかなり遅延すること,さらに多数の絽 返し載荷を受けると CFT 部材も局部座屈するが，耐力の劣化はただ ちに生じないことがわかる.このように, 次節で述べる極短柱の場合 を除けば, CFT 部材の繰返し軸力下での充填コンクリートの効果は, 部材の圧縮耐力の増大よりも，局部座屈発生を遅延させること，局部 座屈後の耐力少化を防ぐこと,および鋼管の破断を遅延させることに ある。

(2) CFT 部材の引張降伏後の曲げ座屈と安定挙動の条件 II（繰返し 軸力下で弦材が合成断面としての圧縮耐力を保持する条件）

充填コンクリートは, 引張を受けるとひび割れが生じるが, その状 態から圧縮してもひび割れが閉じるまでは何の抵抗も示さない.つま り,CFT 部材は引張で塑性化すると次に圧縮されるときは中空鋼管部 材と同じである．図 10 は，鋼管は冷間成形で $D / T$ は約 $30 ， \sigma_{y}$ は約 390MPa， $\sigma_{B}$ は約 30MPa の CFT 部材の座屈曲線である ${ }^{5)}$ が，部材に
は前もって $2 \%$ の弾塑性伸び歪（引張予歪）が与えられている。 こ の座屈曲線は不連続で, 座屈長さが不連続点より長いと中空鋼管部材 として座屈するが，短いと CFT 部材として座屈する．ただし，ここ での座屈とは横たわみが増大して最大庄縮軸力に達することを意味す る.座屈長さが不連続点より短い場合は，充填コンクリートのひび割 れが閉じ始めるまでは横たわみが進行するが,閉じ始めてからは横た わみは減少に転じ,ひび割れが密着したときはほほ真直になって,さ らに軸力が増加すると再び横たわみが増大し最大圧縮軸力に到るとい う経過をたどる.

不連続点の座屈長さは, 鋼管と充填コンクリートの強度および鋼管 の径厚比によって変化する. 文献 4) では, 不連続点での座屈長さと 弾塑性引張予歪の関係を鋼管と充填コンクリートの応力歪関係をバイ リニアーと仮定して示した. しかし，実際はバウシンガー効果によっ て鋼管の応力歪関係は丸みを帯びたものになり,バイリニアーの応力

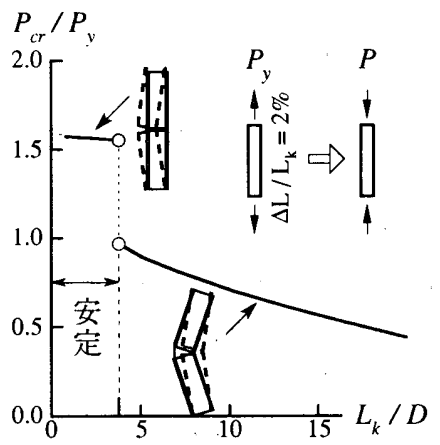

図10 引張降伏後のCFT部材の座屈曲線

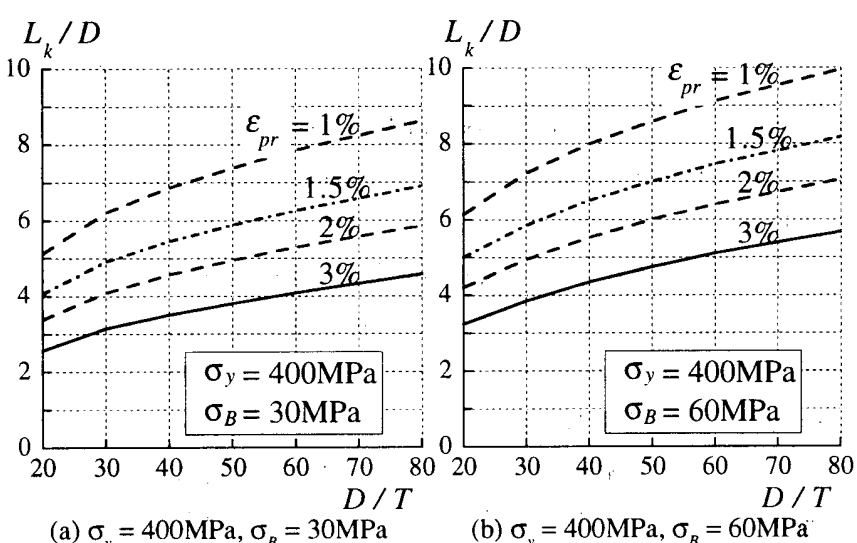
図11 合成断面耐力を保持する条件「安定挙動の条件 ॥」 


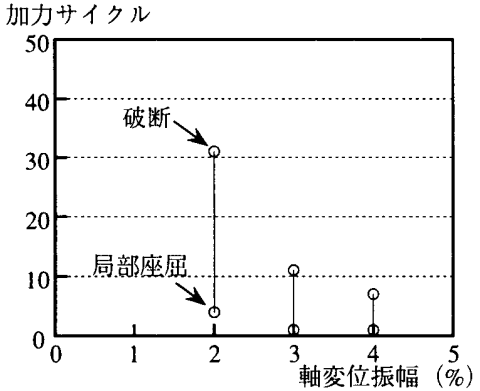

図12 局部座屈と破断の加力サイクル $\quad(D / T=30)$

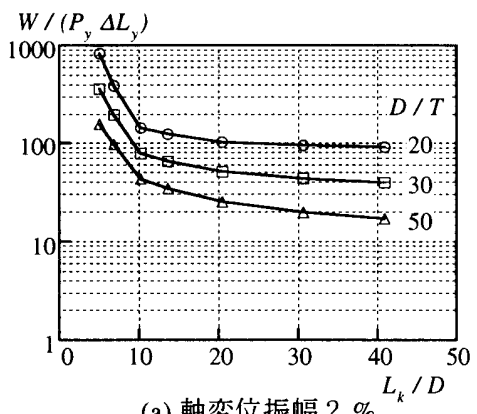

(a) 軸変位振幅 $2 \%$

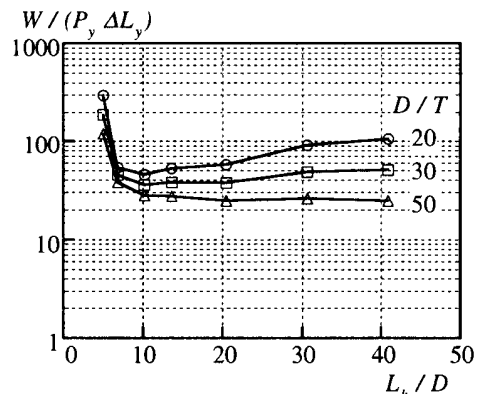

(b) 軸変位振幅 $4 \%$

図13＼cjkstart破断までの無次元化吸収エネルギー

歪関係を仮定した計算値より不連続点の座屈長さはかなり長くなる. そこで, 文献7),8）に示した解析手法で, 鋼管のバウシンガー部分の 履歴曲線を Menegotto-Pinto モデルで近似し, 充填コンクリートも Popovics モデルで近似して, 一次元有限要素法に基づく数值解析を 行った. 鋼管の降伏応力度 $\sigma_{y}$ は 400MPa とし, Menegotto-Pinto モデ ルでは弾塑性歪が $2 \%$ のとに応力が $\sigma_{y}$ に一致するようにモデル変 数を調整した. Popovics モデルでは, コンクリートの圧縮強度 $\sigma_{B}$ を $30 \mathrm{MPa}$ と $60 \mathrm{MPa}$ の 2 種類とし, ヤング率をそれぞれ $25000 \mathrm{MPa}$, $32000 \mathrm{MPa}$ ，ピーク時の歪は両者とも $0.3 \%$ にた。荷重条件は，ま ず, 所定の塑性引張予歪まで引張で降伏させ, 次に鋼管外径 D の $1 \%$ の等偏心圧縮を作用した.座屈長さが不連続点近傍にあると部材の圧 縮耐力が急変するので, 不連続点より少し短いところに座屈長さの限 界点を定めることにした。この限界点は, 充填コンクリートのひび割 れが閉じたときに部材がほほ真直になること(横たわみが鋼管外径 $D$ の $1 \%$ 以内に復帰) を条件として求めた.

図11(a),(b) は, 以上の結果を示したもので, 横軸は鋼管の径厚比 $D / T$, 縦軸は座屈長さ-鋼管外径比 $L_{k} / D$ で, 塑性引張予歪 $\varepsilon_{p r}$ が $1 \%$, $1.5 \%, 2 \%$, および $3 \%$ のとのCFT 部材として座屈する限界点を表し ている、これを「安定挙動の条件 II」と呼ぶことにする.

\section{（3）局部座屈後破断}

図 12 は, 鋼管の $D / T$ が 30 の CFT 部材に正負交番の一定軸方向変 位振幅を与えたときの局部座屈発生と破断時の加力サイクル数の実験 結果である7),8)、横軸は, 材長で無次元化した軸方向変位の全振幅 (た とえば士 $1 \%$ のきは $2 \%)$ を表し，縦軸は局部座屈あるいは破断発生 時の加力サイクル数を表す. 鋼管の局部座屈が観察された後, さらに 破断までにかなりの加力サイクルが必要である.したがって, CFT 部 材の变形限界を局部座屈で規定することは不経済である.

図 13(a),(b) は，正負交番の一定軸方向変位振幅を与えた冷間成形
電縫鋼管 $(S T K 400, D=101.6 \mathrm{~mm})$ に対する無次元化吸収エネルギー $W /\left(P_{y} \Delta L_{y}\right)$ の例7),8)で, 図(a) は座屈長さで無次元化された軸方向変 位の全振幅 (無次元化軸変位振幅) が $2 \%$ の場合, (b) は $4 \%$ の場合で ある.ここで,Wは破断までに吸収されたエネルギー, $P_{y}$ は鋼管の引 張降伏軸力, $\Delta L_{y}$ は降伏軸方向变位 (鋼管の引張降伏軸力に対する弾 性軸方向変位 $)$ を表す. W/ $\left(P_{y} \Delta L_{y}\right)$ は, 座屈長さがごく短い場合 $\left(L_{k}\right.$ $/ D$ が 5 程度以下) では大きく, 長く場合 ( $L_{k} / D$ が 10 程度以上) では 低い值で径厚比ごとにほほ一定になる.また, 軸変位振幅が大きい方 がW/ $\left(P_{y} \Delta L_{y}\right)$ が小さくなる傾向が強いが, $L_{k} / D$ の值が大きいと逆 転する部分もある. 3.3 節ではトラスの部材角が高々 $2 \%$ だとすると $\varepsilon_{p r}{ }^{+} つ ま り$ 弦材要素の無次元化軸変位の塑性成分は高々 $2.4 \%$ あ゙る ことを示した。これより図 13 (b) の無次元化軸変位の全振幅 $4 \%$ は実 用範囲をほほ包含していると考えられる. 図13(a)と (b)のうち小さ い方のW/ $\left(P_{y} \Delta L_{y}\right)$ を読みとると, 座屈長さがごく短い場合では, 径 厚比が 20 で 300 程度, 径厚比が 30 で 200 程度, 径厚比が 50 で 100 程度であり, 座屈長さが長い場合では, 径厚比が 20 で 50 程度, 径 厚比が 30 で 40 程度, 径厚比が 50 で 20 程度になっている. ただし, これらの值は今後さらに実験データを蓄積して確認する必要がある。

\subsection{CFT トラスの繰返し荷重下の挙動}

図14 は, 一定軸力 $N$ と正負交番の水平力 $H$ を受ける 4 格間のワー レン形トラス柱の曲げせん断実験である21. $N$ はトラスの圧縮耐力 $N_{0}$ の $10 \%$ あるいは $0 \%$ である. $N_{0}$ は両弦材の圧縮耐力の和で, CFT ト ラスは $A_{s} \sigma_{y}+A_{c} \sigma_{B}$, 中空鋼管トラスは $A_{s} \sigma_{y}$ であり, $A_{s}, A_{c}$ は鋼管 部分とコンクリート部分の断面積である. トラスの柱脚は固定で, 自 由端と材中央は構面外に補剛されている. 弦材鋼管の $D / T$ は約 $30, \sigma_{y}$ は約 370MPa，充填コンクリートの $\sigma_{B}$ は約 30MPaである.

図 15(a) と(b) は，N/N が 10\%のときの中空鋼管トラスと CFT ト



図14 トラス柱モデル

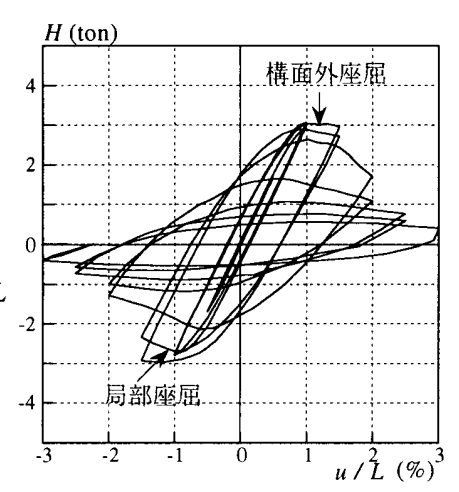

(a) 中空鋼管トラス柱, $N / N_{0}=0.1$

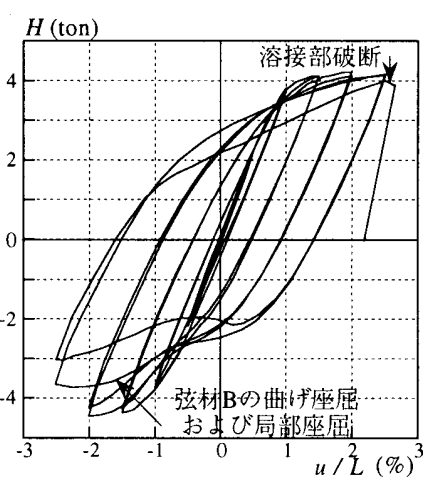

(b) CFTトラス柱, $N / N_{0}=0.1$

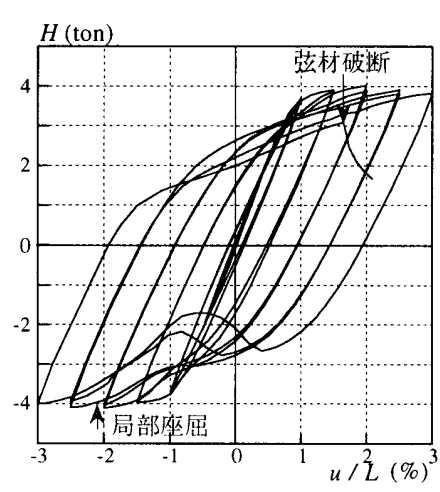

(c) CFTトラス柱, $N / N_{0}=0.0$ 図15 CFT トラス柱および中空鋼管トラス柱の繰返し曲げせん断挙動 
ラスの水平荷重 $H$ - 水平変位 $u$ 関係で, CFT トラスの繰返し履歴特 性が中空鋼管トラスに比較して大幅に向上していることがわかる.中 㞬鋼管トラスの耐力劣化は,トラスの構面外座屈によって引き起こさ れている．図 15(b) の CFTトラスは，弦材 A は座屈せず, 弦材 B の みが座屈している，その結果，弦材 $\mathrm{A}$ が圧縮となるときの反転点荷 重 [図15(b)の正側反転点] はほとんど低下していない。この場合の安 定挙動は, 弦材 A の軸力が弦材 B の引張降伏によって座屈軸力を越 えない「安定挙動の条件 I」を満たしていること,さらに弦材 $\mathrm{A}$ が 引張降伏しても合成断面としての圧縮耐力を保持する「安定挙動の条 件 II」を満たしていることによって実現されている，片方の弦材に 対してこの二つの条件を満たすことは比較的容易である.

図 15(c) は軸力 $N$ が 0 のCFT トラスを示している:この場合は両 弦材とも安定挙動の条件 I と II を満たしている.部材角振幅が増大 すると局部座屈によるスリップ形の履歴特性が現れるが,どちらの加 力方向でも反転点荷重は劣化しない.これは弦材にコンクリートを充 填したトラスだけに期待できる優れた特徵と言える.

\section{3 両弦材とも座屈しないCFT トラスの変形能力}

CFTトラスが繰返し荷重を受ける場合に両弦材が座屈すると軸方向 の不安定が生じ, 耐力が急速に劣化するので, 少なくとも片方の弦材 は座屈させないようにするべきである.まず, 両弦材とも座屈させな い場合には, 両弦材に対して安定挙動の条件 I と II を満足させる必 要がある。ここではCFTトラスが曲げせん断を受けて材端の1区間 の弦材要素のみが塑性化する場合に限定して安定挙動の条件 I と II の 検定方法と変形能力の評価を試みる.

\section{(1) 安定挙動の条件 II とその検定}

安定挙動の条件 I の検定は, 図 5 に示した M-N 相関耐力,上でトラ スの軸力 $N$ が正および負の曲げモーメントに対する $\mathrm{G}$ 点の軸力以下 になっていることを確認すればよい. 安定挙動の条件 II の検定は, 弦 材の座屈長さ $L_{k}$ が弦材に生じる引張予歪に対応する条件 II の限界值 以下であることを確認すればよい.この場合の $L_{k}$ は, 充填コンクリー トのひび割れが閉じる前までの中空鋼管部材としての軸カレベルに対 応するので, 隣接弦材要素が弾性であれば固定支持されていると考え てよい.つまり，弦材材端が固定支持されていれば $L_{k}$ は $0.5 l （ l$ は弦 材の区間長)，ピン支持されていれば 0.71 に等しいとすることができ る. 材端の弦材要素の塑性引張予歪 $\varepsilon_{p r}$ の算定は, 図6に示す曲げせ ん断を受けるトラスの場合,横力の正負およびその場合に曲げ引張側 になる弦材要素の諸量に'+', '○の記号を付けて表すと近似的に次式 のようになる。

$$
\varepsilon_{p r}^{+}=\frac{h}{l^{+}} R_{p u}^{+}, \quad \varepsilon_{p r}^{-}=\frac{h}{l^{-}} R_{p u}^{-}
$$

終局状態におけるトラスの部材角は高々 $2 \%$ 程度であるとし, そのう ち弾性限部材角を $0.6 \%$ とすれば, 終局状態での塑性部材角 $R_{p u}$ は高々 $1.4 \%$ 程度になる．たとえば，図6に示すワーレン形トラスでウェブ 材の斜角を 60 度とし，弦材鋼管の $\sigma_{y}$ を $400 \mathrm{MPa}$ とすれば, “式(4) か ら $\varepsilon_{p r}^{+}$あるいは $\varepsilon_{p r}^{-}$はそれぞれ次のように求められる。

$$
\varepsilon_{p r}^{+}=\sqrt{3} \cdot 0.014=0.024, \varepsilon_{p r}^{-}=\frac{\sqrt{3}}{2} \cdot 0.014=0.012
$$

充填コンクリートの $\sigma_{B}$ を $30 \mathrm{MPa}$, 弦材鋼管の $D / T$ を 30 とすれば, 図 11(a)から条件 II を満たす弦材要素の座屈長さの上限值が $l^{+}$と $l$ に
対してそれぞれ $3.6 D$ および $5.5 D$ 程度と読みとれる.弦材材端の支持 が固定とすれば $l^{+}$とにをそれぞれ $7.2 D$ および $11 D$ 以下になるよう に寸法を決めれば，安定挙動の条件 II が満たされることになる.

(2) 変形能力

エネルギーの等価性から, 塑性化する弦材要素の加力片側の平均累 積塑性変形倍率 $\eta_{b k}$ をそれが破断するまでの無次元化吸収エネルギー $W_{b} /\left(P_{y} \Delta L_{y}\right)$ の $1 / 2$ とおくことにすると，次式が成立する.

$$
W_{b}=2 \eta_{b k} \cdot P_{y} \cdot \Delta l_{y}=2 \eta_{b k} \cdot P_{y} \cdot \varepsilon_{y} l
$$

ここで, $W_{b}$ : 弦材要素の破断までの吸収エネルギー, $P_{y}:$ 弦材の引 張降伏軸力, $\varepsilon_{y}=\sigma_{y} / E$ : 鋼管の降伏ひずみ, $\sigma_{y}$ : 鋼管の降伏応力度, $E$ : 鋼管のヤング率, $l$ : 降伏する弦材要素の節点間距離を表す. 両弦 材とも座屈しないトラスは, 両弦材がエネルギーを吸収する。トラス の加力片側の累積塑性変形倍率 $\eta_{k}^{+}, \eta_{k}^{-}$は，それぞれの場合に曲げ引 張側になる弦材要素の全吸収エネルギーに対応すると考えることがで きて，次の関係が得られる.

$$
\begin{gathered}
\eta_{k}^{+}=\frac{W_{b}^{+}}{P_{y} h R_{p c}^{+}}=2 \eta_{b k}^{+} \frac{l^{+}}{h} \frac{\varepsilon_{y}}{R_{p c}^{+}} \\
\eta_{k}^{-} \stackrel{\frac{W_{b}^{-}}{P_{y} h R_{p c}^{-}}}{=}=2 \eta_{b k}^{-} \frac{l^{-}}{h} \frac{\varepsilon_{y}}{R_{p c}^{-}}
\end{gathered}
$$

$\eta_{k}^{+}, \eta_{k}^{-}$の評価に用いる弦材要素の座屈長さは, 充填コンクリートのひ び割れが閉じるまでの軸力レベルに対応するので, 安定挙動の条件 II と同様に考えることができる.トラスの加力片側の累積塑性変形倍率 $\eta_{k}$ は, $\eta_{k}^{+}, \eta_{k}^{-}$のうち小さい方の值をとれば安全側評価になる：CFT トラスの変形能力を鋼構造の充腹柱に対する方法9)で評価してみる. トラスの変形能力 $\eta_{0}$ は, 上述の塑性変形倍率 $\eta_{k}$ からバウシンガー 領域のエネルギー吸収を除いたものとすれば, 簡単には次のように与 えられる。

$$
\eta_{0}=\frac{2}{3} \eta_{k}
$$

\section{4 片方の弦材が座屈する場合の変形能力}

片方の弦材の座屈を許容する場合のトラスの履歴曲線は, 座屈する 弦材が曲げ圧縮側になるときは劣化型特性が現れ; 曲げ引張側になる ときは劣化型特性が現れず, 左右非対称なものになる.弦材の座屈後 の耐力劣化が急激であればその履歷特性も好ましいものにはならない ので, 少なくとも弦材の座屈長さを文献9)，10）に示されている制限 值以内にすることが望ましい.このときの弦材の座屈荷重の算定に使 用する座屈長さは, 合成断面部材としての座屈に対応するもので, 隣 接弦材要素が弾性でも必ずしも固定の境界条件とは見なせない.しか し, 曲げ座屈变形が進行した後の状態に対応する座屈長さは, 純鉄骨 トラスに関する文献 9) の提案に従って, 節点間 $l$ で座屈する場合は $0.5 l$, 構面外座屈する場合は横補剛支点間距離の $0.7 l_{b}$ （ $l_{b}$ は横補剛支 点間距離）とすることができる。

片方の弦材の座屈を許容する CFTトラスの $\eta_{k}$ は, トラスの変位応 答が一方向に偏らないとすれば加力の正側と負側の平均值を用いるこ とができる。つまり, 累積塑性変形倍率 $\eta_{k}$ は, 座屈した弦材要素の 吸収エネルギー量の二分の一に対応するので次の関係が得られる。

$$
\eta_{k}=\frac{W_{b}}{2 P_{y} h R_{p c}}=\eta_{b k} \frac{l}{h} \frac{\varepsilon_{y}}{R_{p c}}
$$

上式の右辺の諸量は, 座屈する弦材要素に関するものを表す. 


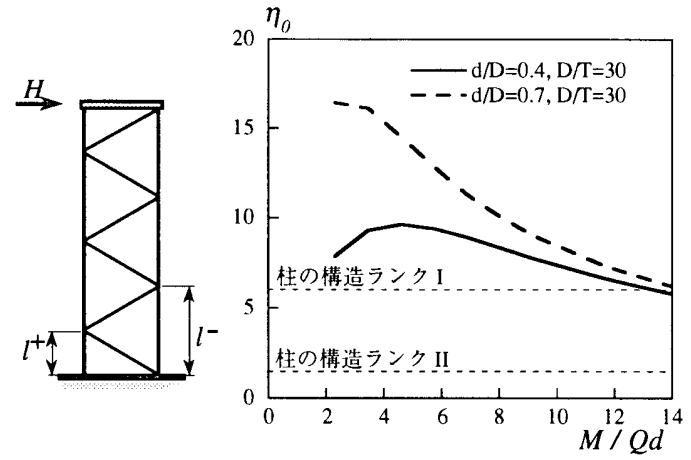

(a) 両弦材とも座屈しない場合の $d / D$ の影響



(b) 両弦材とも座屈しない場合の $D / T$ の影響

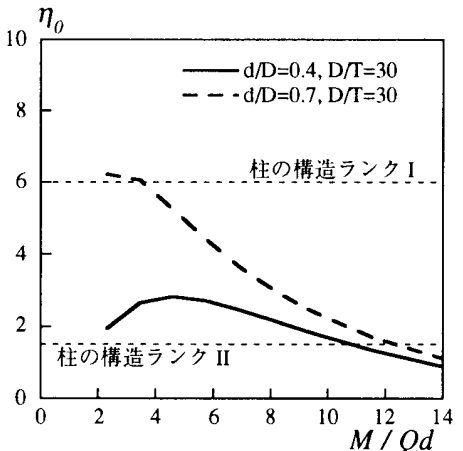

(c) 片方の弦材が座屈する場合

図16 繰返し荷重下のCFT トラス柱の塑性变形能力

変形能力は, やはり文献 9)に従う充腹柱として評価すれば, 酎力 劣化域のエネルギー吸収に割引を行って次式で与えられる.

$$
\eta_{0}=\frac{2}{3} \eta_{k}-2
$$

\section{5 繰返し曲げせん断を受ける CFT トラスの変形能力の評価例}

CFTトラスモデルはウェブ材斜角が 60 度のワーレン形CFTトラス 柱で一つの格間に対する弦材要素の材長は約 $10 D$ (区間 $l^{+}$は $5 D$ ) である. 弦材要素の $\eta_{b k}$ の評価のための $L_{k} / D$ は, 弦材材端が固定さ れているとすると高々 5 になる， $\eta_{b k}$ は 3.1 節で述べた短柱の無次元 化吸収エネルギーの半分に相当するが, 破断現象のばらつきを考虑し てその半分を有効と考え, 弦材の $D / T$ が 20 のとき $75, D / T$ が 30 の とき $50, D / T$ が 50 のとき 25 とする. 両弦材とも座屈しない場合と 片方の弦材が座屈する場合についてそれぞれ式(7)と(8), および式(9) と(10)を適用すると， $\eta_{0}$ は図16(a)〜(c) のとおりとなる．両弦材とも 座屈しない場合が図 16(a)および(b)で, CFTトラスの変形能力 $\eta_{0}$ は, $M / Q d$, ウェブ材断面, さらに弦材の $D / T$ に大きく影響されること がわかる.ウェブ材断面が大きいCFTトラスはほぼ柱の構造ランク I 9)に該当し, 鉄骨充腹柱にも匹敵する.一方, 片方の弦材が座屈する 場合 [図 16(c)] は, 両弦材とも座屈しない場合と比較して $1 / 3$ 以下 に低下するが，柱の構造ランク II は期待できる．

2.2 節で示した一方向荷重下の場合の変形能力は, 弦材の $D / T$ に よる影響は小さいが，繰返し荷重下の場合では大きい.したがって， 繰返し荷重下と一方向荷重下での変形能力は少なくとも CFTトラス については直接比較することができない.

なお, 以上のCFTトラスの変形能力は, 弦材の破断までのエネル ギー吸収を $1 / 2$ まで低減して評価したが，鋼管の製法，サイズ，温 度, 歪速度などによっては早期破断の危険性が残されているので, 今 後さらに実験資料を蓄積する必要がある。

\section{4. 結論}

両弦材がCFTで構成された平行弦鋼管トラスの単調あるいは繰返 し荷重下の変形能力の評価を試みた結果, 次の結論が得られた. (1)一方向の曲げせん断を受けて而弦材とも座屈しないCFTトラスは, 安定挙動の条件 I を満たすことによって実現される。このときの変形 能力は少なくとも 3 から 10 程度が期待できるが, ウェブ材断面の大 小とトラスのせん断スパン比に強く影響を受ける。

(2) 繰返し曲げせん断を受けても両弦材とも座屈しないCFTトラスは,
両弦材とも安定挙動の条件 I と II 満たすことによって実現される. このときの変形能力はウェブ材断面の大小およびせん断スパン比のほ か弦材鋼管の径厚比に強く影響を受ける。また，ウェブ材断面が大き な場合の変形能力は鉄骨充腹柱に匹敵する.

(4) 片方の弦材だけが安定挙動の条件 I と II を満たす CFTトラスは, 他方の弦材が座屈する.このときの変形能力は, 両弦材とも座屈しな い場合と比較してかなり低下するが鉄骨充腹柱としての構造ラジク II 程度は期待できる。

(4) 一方向荷重下と繰返し荷重下での変形能力は少なくともCFTトラ スについては直接比較できない.これは今後の課題と考える.

\section{参考文献}

1) 松井千秋, 河野昭彦, 大串勝利：弦材にコンクリートを充填した 鋼管トラス柱の曲げねじれ座屈挙動と耐力評価, 日本建築学会構 造系論文集，第459号，1994.5, 169-176.

2) 河野昭彦, 松井千秋, 崎野良比呂: 繰返し水平力を受けるコンク リート充填鋼管トラス柱の弾塑性挙動と変形能力に関する実験的 研究, 日本建築学会構造系論文集, 第 482 号, 1996.4, pp.141 150.

3) C. Matsui and A. Kawano: Strength and Behavior of Concrete-Filled Tubular Trusses, The International Speciality Conference on Concrete Filled Steel Tubular Structures, Harbin, China, 1988.8, 113-119.

4) 河野昭彦, 松井千秋：軸引張塑性履歴を受けたコンクリート充填 鋼管部材が単調圧縮耐力を保持する条件, 日本建築学会構造系論 文報告集，第 448 号，1993.6，153-162.

5) 河野昭彦, 松井千秋, 崎野良比呂, 中島隆裕: 軸引張塑性履歴が ある鋼管コンクリート部材の曲げ座屈荷重に関する実験的研究, 日本建築学会構造工学論文集, Vol. 39B, 1993.3, 335-342.

6) A. Kawano and C. Matsui: An Experimental Study on Hysteretic Behavior of Concrete Filled Tubular Members under Repeated Axial Loading, Proc. of Ninth World Conference on Earthquake Engineering, TokyoKyoto, Vol. IV, 1988.8, IV-133-138.

7) 河野昭彦，松井千秋，中島隆裕，高木潤一：繰返し軸方向力を受 けるコンクリート充填鋼管部材の座屈挙動とエネルギー吸収能力 に関する実験的研究, 日本建築学会構造系論文報告集, 第 482 号, 1996.4, 131-140.

8) A. Kawano and C. Matsui : Buckling Behavior and Aseismic Property of Concrete-filled Tubular Members Under Cyclic Axial Loading, Proceedings of an Engineering Foundation Conference on Composite Construction in Steel and Concrete III, ASCE, 1997.8, 602-615.

9）日本建築学会：建築耐震設計における保有耐力と変形性能, 1990.10 .

10) 日本建築学会: 鋼管構造の挙動と設計に関する最近の研究, 鋼管 構造シンポジウム資料, 1994.5 .

11) 新都市ハウジング協会: CFT 構造技術指針・同解説, 1997.1. 